\title{
ALTERNATIF PEMBELAJARAN MATEMATIKA MENGGUNAKAN MEDIA PAPAN ARSIR PECAHAN
}

\author{
Delia Indrawati ${ }^{1)}$, Dewi Nur Cahyanti ${ }^{2)}$ \\ Universitas Negeri Surabaya \\ Email: deliaindrawati@unesa.ac.id, dewicahyanti@mhs.unesa.ac.id
}

\begin{abstract}
Abstrak
Pembelajaran merupakan kegiatan yang membawa peserta didik memahami materi, ilmu pengetahuan, dan juga pengalaman untuk bekal kehidupannya di masa mendatang. Salah satu komponen dalam menunjang pembelajaran ialah media pembelajaran. Media memiliki peran penting dalam menyampaikan pesan dari guru kepada siswa salah satunya dalam materi matematika. Mengajarkan matematika di Sekolah Dasar haruslah disesuaikan dengan beberapa hal. Matematika Sekolah Dasar mencakup materi-materi yang diajarkan dengan konsep-konsep dan sesuai teori belajar yang mendukung. Penanaman dan pemahaman konsep dari suatu materi memerlukan proses pembelajaran yang menarik dan sesuai agar tidak menjadikan peserta didik mengalami miskonsepsi, untuk itu diperlukan alternatif pembelajaran yang sesuai salah satunya ialah papan arsir pecahan. Papan arsir pecahan merupakan media visual yang dikembangkan menggunakan papan yang berasal dari papan melamin dan akrilik yang dilapisi kain flanel. Media papan arsir pecahan merupakan media yang penggunaannya dengan cara diarsir. Media papan arsir pecahan akan memberikan penjelasan mengenai konsep operasi hitung pecahan. Media pembelajaran yang papan arsir pecahan ini memiliki komponen - komponen yaitu : (1) Papan utama (2) Papan arsir transparan (3) Papan Arsir tidak trasparan (4) buku petunjuk (5) Alat untuk mengarsir (Spidol) (6) box (7) Penghapus. Komponen-komponen tersebut dapat digunakan sebagai alternatif pembelajaran matematika di Sekolah Dasar.
\end{abstract}

Kata Kunci: Media Papan Arsir bongkar pasang, Pembelajaran Matematika, Operasi Hitung Pecahan.

\section{Pendahuluan}

Pembelajaran di kelas mempengaruhi pemahaman siwa dan juga keaktifan siswa dalam belajar. Pembelajaran merupakan kegiatan yang membawa peserta didik dalam memahami materi, ilmu pengetahuan, dan juga pengalaman untuk bekal kehidupannya di masa mendatang. Salah satu komponen dalam menunjang pembelajaran yang juga berpengaruh ialah media pembelajaran. Media memiliki peran penting dalam menyampaikan pesan dari guru kepada siswa.
Menurut Gerlach \& Ely (dalam Arsyad 2014:03) mengatakan bahwa media adalah manusia, materi atau kejadian yang membangun kondisi yang membuat siswa mampu memperoleh pengetahuan, keterampilan, atau sikap. Dalam pengertian tersebut mengandung artian bahwa media berasal dari berbagai sumber yang dapat menjadikan siswa memperoleh pengalaman dan pengetahuan yang luas. Pelaksanaan pembelajaran akan lebih mudah tersampaikan 
apabila menggunakan media pembelajaran sebagai penyampai pesan. Media pembelajaran yang digunakan dalam kelas memiliki fungsi memberikan penjelasan bagi peserta didik dalam memperjelas dan mempermudah konsep yang kompleks dan abstrak menjadi sederhana, konkrit dan mudah dipahami sehingga dapat mendorong siswa untuk bersemangat dalam belajar. Hamalik (dalam Arsyad, 2014:11) mengemukakan bahwa pemakaian media pembelajaran dalam proses belajar mengajar dapat membangkitkan keinginan dan minat yang baru, membangkitkan motivasi dan rangsangan kegiatan belajar mengajar, dan bahkan membawa pengaruh-pengaruh psikologis terhadap siswa. Media diperlukan dalam menyampaikan pembelajaran yang ada di Sekolah Dasar salah satunya ialah pembelajaran Matematika. Matematika merupakan pembelajaran yang penting untuk disampaikan dan juga di pahami oleh siswa.

Mengajarkan matematika di Sekolah Dasar haruslah disesuaikan dengan beberapa hal yang harus diperhatikan. Matematika Sekolah Dasar mencakup materi-materi yang harus diajarkan dengan konsep-konsep dan dilakukan sesuai teori-teori belajar yang mendukung. Pola pembelajaran yang dilakukan dalam matematika adalah dengan memberikan pengalaman belajar kepada siswa sesuai dengan konsep-konsep yang akan dipelajari. Hal ini sejalan dengan teori yang diungkapkan oleh Jerome S.Brunner. Proses belajar siswa dalam memahami matematika menurut bruner (dalam Ridwan, 2014:15) perlu adanya tahap-tahap sebagai berikut : a) memanipulasi objek, b) representasi gambar, c) manipulasi simbol. Menurut Heruman (2012: 02) konsep-konsep pada kurikulum yang ada di Sekolah Dasar dapat dibagi menjadi tiga kelompok, yaitu : penanaman konsep dasar, pemahaman konsep, dan pembinaan keterampilan. Dalam ketiganya menjadikan siswa dapat memiliki keterampilan matematika dan menguasai konsep yang nantinya dapat diaplikasikan dalam kehidupan sehari-hari. Penanaman dan pemahaman konsep dari suatu materi matematika memerlukan proses pembelajaran yang menarik dan sesuai agar pelaksanaanya tidak menjadikan peserta didik mengalami miskonsepsi, untuk itu diperlukan alternatif pembelajaran yang sesuai.

Menurut Heruman (2012 : 43), pecahan adalah bagian dari sesuatu yang utuh. Bagian yang dimaksud adalah bagian yang diperhatikan biasanya ditandai dengan adanya arsiran yang menunjukkan dari nilai besar pecahan. Pada bagian yang diarsir disebut sebagai pembilang dan bagian utuh disebut sebagai penyebut Pecahan merupakan bagian bilangan dari bilangan rasional yang ditulis dalam bentuk rumus $\frac{a}{b}$ dengan a dan $b$ merupakan bilangan bulat dan b tidak sama dengan nol, a disebut pembilang, $b$ disebut penyebut. Materi pecahan ini dibagi beberapa materi yang mendasar seperti operasi hitung pecahan. materi-materi pecahan ini merupakan salah satu materi yang penting di Sekolah Dasar, akan tetapi dalam faktanya tidak semua siswa memahami konsep materi secara benar. Proses pembelajaranlah yang mempengaruhi hal tersebut, dalam pelaksanaan pemahaman konsep diperlukan pemahaman yang benar dari guru untuk dapat menyampaikan materi dan juga perlunya media penunjang yang sesuai dalam menjelaskan kepada siswa mengenai materi. Memahami materi operasi hitung pecahan memerlukan media pembelajaran yang menjelaskan secara real dan konkret bagi siswa sehingga siswa tidak hanya mengetahui hasil dan pengerjaan secara langsung melainkan juga dengan 
mengetahui konsep operasinya. Dalam mengajarkan mengenai konsep pecahan guru pertama kali hendaknya menggunakan objekobjek yang nyata misalnya dengan berbagai benda seperti : apel, semangka, sawo, dan sebagainya, sedangkan pada konsep operasi hitung pecahan guru dapat menggunakan media seperti papan arsir pecahan.

Papan arsir pecahan merupakan papan arsir yang dibuat dengan memberikan tempat untuk dapat diasir dan dihapus sesuai dengan soal yang ada pada operasi hitung pecahan. papan arsir pecahan merupakan papan arsir yang terdiri dari papan arsir transparan dan papan arsir tidak transparan. Papan arsir pecahan merupakan papan arsir yang konsep dan pelaksanaannya sesuai dengan media mika transparan. Papan flanel adalah media papan yang digunakan untuk menyajikan pesan-pesan tertentu yang pembuatannya berlapiskan dengan kain flanel (Sadiman, 2014). Pada media papan arsir pecahan konsep papan utama yang dibuat akan sama dengan pembuatan papan flanel. Pada papan ini media yang ditempelkan akan mudah dipasang dan dicopot secara bergantian.

Berdasarkan penjelasan tersebut untuk pemudahan dalam pemakaian dan juga penggunaan akan dilengkapi beberapa petunjuk penggunaan media pembelajaran ini, untuk itu media pembelajaran ini akan sesuai dalam penggunaan dalam pembelajaran matematika khususnya pada materi operasi hitung pecahan.

\section{Gagasan Ilmiah}

\section{A. Media papan arsir pecahan (Media}

\section{Pembelajaran operasi hitung pecahan)}

Papan arsir pecahan merupakan media visual yang dikembangkan menggunakan papan yang berasal dari papan melamin dan juga akrilik yang dilapisi kain flanel. Media papan arsir pecahan merupakan media yang penggunaannya dengan cara diarsir. Media papan arsir pecahan akan memberikan penjelasan mengenai konsep operasi hitung pecahan mulai dari penjumlahan, pengurangan, perkalian dan juga pembagian. Media papan arsir pecahan ini berfungsi untuk menunjang pembelajaran atau alternatif terbaru untuk pembelajaran matematika materi operasi hitung pecahan yang efisien, praktis, dan mudah dalam penggunaanya. Pelaksanaan proses pembuatan dan juga inti dari konsep materi yang akan dijelaskan disesuaikan dengan beberapa konsep yang sudah ada dalam matematika yang ada pada penjelasan buku Heruman (2012) dan juga Van De Walle (2008), media papan arsir pecahan merupakan media yang dikembangkan dari adanya media mika transparan sehingga konsep materi didalamnya sama dengan media mika transparan.

Media pembelajaran yang papan arsir pecahan ini memiliki komponen - komponen yaitu : (1) Papan utama (2) Papan arsir transparan (3) Papan Arsir tidak transparan (4) buku petunjuk materi pelajaran, rumus, dan soal latihan (5) Alat untuk mengarsir (Spidol) (6) box (7) Penghapus. Berikut ini penjelasan mengenai komponen media :

1) Papan Utama

Papan utama merupakan komponen utama dari media pembelajaran yang ada. Papan ini digunakan untuk meletakkan papan arsir tansparan dan papan arsir 
tidak transparan. Beberapa hal yang terdapat dalam papan utama ini seperti tulisan nama media dan tempat soal pecahan dan hasil pecahan. Ukuran dari papan utama adalah $100 \mathrm{~cm}$ x $80 \mathrm{~cm}$ dengan jumlah 1 buah.

\section{2) Papan Arsir tidak transparan}

Papan Arsir tidak transparan merupakan papan yang digunakan untuk tempat mengarsir pecahan. Papan ini sebagai papan pertama yang ditempel di papan utama. papan ini dibuat dengan ukuran yang sama dengan papan arsir tidak transparan. Ukuran yang digunakan dalam papan arsir tidak transparan adalah $40 \mathrm{~cm} \mathrm{x} 40 \mathrm{~cm}$.

3) Papan Arsir Transparan

Papan arsir transparan adalah papan yang digunakan dengan cara diarsir, papan ini setelah diarsir diletakkan diatas papan arsir tidak transparan. Ukuran yang digunakan dalam papan arsir tidak transparan adalah $40 \mathrm{~cm} \mathrm{x} 40 \mathrm{~cm}$.

4) Buku Petunjuk

Buku petunjuk merupakan buku yang digunakan sebagai panduan dalam menggunakan media papan arsir pecahan. Dalam buku petunjuk akan dijelaskan mengenai cara pemakaian media papan arsir pecahan. Buku petunjuk ini akan memberikan pemahaman kepada guru untuk menjelaskan materi kepada siswa dengan menggunakan media papan arsir pecahan. Buku ini dilengkapi dengan materi-materi dan latihan soal.

5) Spidol

Spidol merupakan alat yang digunakan untuk mengarsir papan sesuai dengan besarnya nilai pecahan di soal. Spidol yang digunakan menggunakan dua warna yang berbeda sehingga dapat membedakan antara arsiran satu dengan arsiran lainnya.

6) Box

Box merupakan kotak yang digunakan untuk mengemas buku petunjuk dan komponen media yang ada dalam media papan arsir pecahan. Box ini disesuaikan dengan ukuran dari papan arsir transparan dan papan arsir tidak transparan.

7) Penghapus

Penghapus papan digunakan untuk menghapus tulisan spidol di papan agar papan dapat digunakan kembali untuk nilai besar pecahan atau soal yang lainnya.

Berikut ini merupakan beberapa gambar dari komponen media papan arsir pecahan:

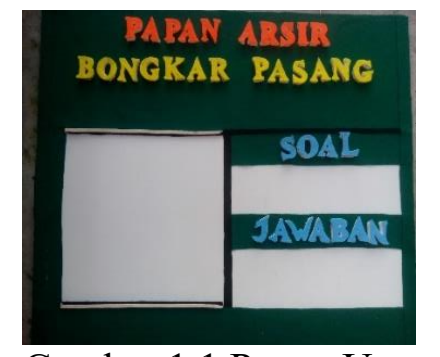

Gambar 1.1 Papan Utama

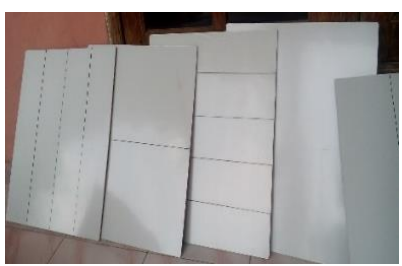

Gambar 1.2 Papan tidak transparan

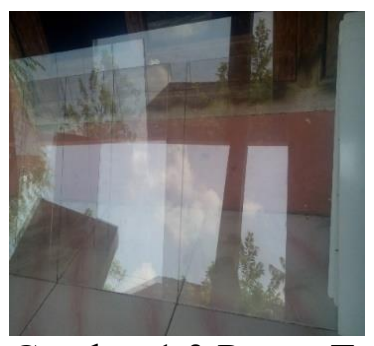

Gambar 1.3 Papan Transparan 


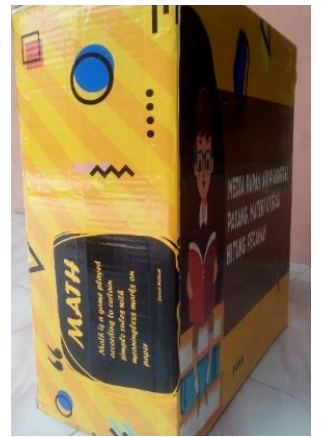

Gambar 1.4 Box

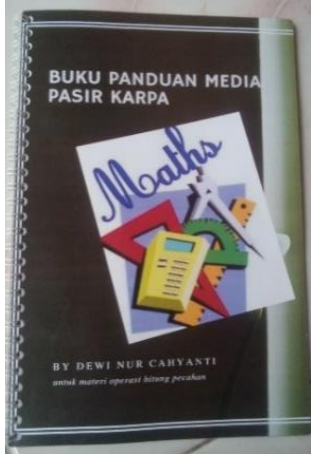

Gambar 1.5 Buku Petunjuk

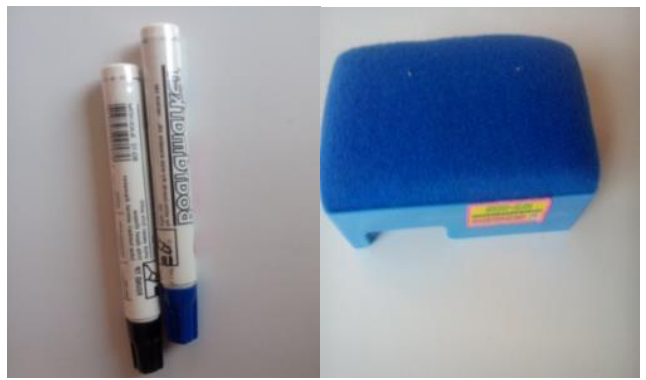

Gambar 1.6 Penghapus dan Spidol

\section{B. PEMBUATAN MEDIA PAPAN ARSIR PECAHAN}

Pelaksanaan pembuatan dimulai dari pemilihan bahan media dan perpaduan bahan satu dengan bahan lainnya serta komponen yang satu dengan komponen lainnya. Fokus pembuatan yang terbesar terletak pada pembuatan papan utama dan papan arsir transparan. Adapun proses pembuatan dari media Papan Arsir Pecahan adalah sebagai berikut :

\section{a) Papan Utama}

Papan utama dan papan arsir tidak transparan dibuat dari triplek melamin putih, hal ini dipilih karena pada triplek tersebut dapat digunakan untuk menulis menggunakan spidol dan bisa dihapus kembali layaknya papan putih di kelas. Setelah bahan papan melamin telah ditentukan langkah selanjutnya ialah memotong papan melamin sesuai pada ukuran di rancangan awal yaitu dengan panjang $100 \mathrm{~cm}$ dan lebar $80 \mathrm{~cm}$. Setelah dilakukan pemotongan dilakukan pengukuran pada letak tulisan dan letak siku alumunium untuk peletakkan. Langkah selanjutnya dalam pembuatan papan utama ialah penentuan lapisan dari triplek yakni menggunakan flanel dengan pemilihan warna yang sesuai dan tidak mudah terlihat kotor. Pemilihan dasar flanel pembungkus triplek dipilih yang sesuai agar dapat dilihat rapi, menarik, dan sesuai untuk mata.

b) Papan arsir transparan dan tidak transparan

Pembuatan pada papan arsir transparan dan papan arsir tidak transparan ialah sama halnya pada penggunaan bahan yang berbeda. Papan arsir transparan menggunakan bahan akrilik hal ini dikarenakan akrilik merupakan bahan plastik tebal atau kaku yang memiliki sifat hampir sama dengan kaca akan tetapi tidak mudah pecah dan lebih ringan, sedangkan bahan yang digunakan untuk membuat papan arsir tidak transparan adalah papan triplek melamin yang bisa untuk menulis dan dapat dihapus. Pemotongan dari bahan akrilik dan triplek untuk pembuatan papan arsir ialah dengan ukuran $40 \mathrm{~cm} \mathrm{x} 40 \mathrm{~cm}$. Pada pembuatan papan arsir transparan dan papan arsir tidak transparan ini sebanyak 5 untuk menentukan nilai besar pecahan. Arah arsiran secara vertikal untuk papan arsir transparan dan arah arsiran secara horizontal untuk papan arsir tidak transparan. Pembuatan papan ini dengan teknik memotong dan mengukur tiap komponen yang akan dibuat. 
c) Box, spidol, penghapus, dan buku panduan.

Pembuatan komponen tambahan seperti box dan buku panduan memerlukan desain yang dibuat menggunakan aplikasi adobe ilustrator dan aplikasi coreldraw. Pembuatan desain disesuaikan dengan karakteristik dari pengguna media sehingga memunculkan desain yang menarik, serta pilihan warna dan gambar yang sesuai. Pembuatan box dengan desain akan digunakan sebagai kemasan media untuk peletakan papan arsir, spidol, penghapus, dan buku panduan. Bahan box yang dibuat menggunakan kardus dengan diberikan stiker dari desain yang telah dibuat, sedangkan pembuatan buku panduan menggunakan kertas art paper dan menggunakan jilid spiral.

\section{Implementasi Papan Arsir Pecahan}

1. Penggunaan Guru dan Peserta didik

Sasaran yang dituju dalam penggunaan media papan arsir pecahan ialah peserta didik kelas IV dan $\mathrm{V}$ yang dalam pembelajarannya memuat materi operasi hitung pecahan mulai dari penjumlahan, pengurangan, pembagian, dan perkalian. Dalam penggunaan dan pelaksanaan harus disesuaikan dengan penggunaan kurikulum, Kompetensi Dasar, dan juga indikator yang telah dibuat oleh guru dalam pembelajaran. Penggunaan media papan arsir pecahan dapat digunakan oleh guru dalam proses pembelajaran berlangsung, media ini sebenarnya juga dapat digunakan langsung oleh siswa akan tetapi perlu pendampingan oleh guru dan adanya buku petunjuk yang mudah dalam pemahaman siswa.

\section{Teknik pelaksanaan}

Teknik pelaksanaan dalam pembelajaran terdapat dua subjek yaitu para guru dan siswa serta objek utamanya adalah media pembelajaran papan arsir pecahan. adapun peran subjek dan obyek dalam pelaksanaannya adalah sebagai berikut:

a. Guru memiliki peran sebagai pelaksana dalam pembelajaran menggunakan media pembelajaran. Proses sukses dan tidaknya pembelajaran menggunakan media ini juga dapat bergantung pada guru. Guru dapat memberikan arahan kepada siswa apabila didapati kesulitan dalam penggunaan media dan juga materi yang ada.

b. Siswa memiliki peran dalam pelaku dan juga sasaran dari keberhasilan dalam alternatif pembelajaran yang digunakan yakni media pembelajaran papan arsir pecahan.

c. Media papan arsir pecahan merupakan alternatif media pembelajaran pada materi operasi hitung pecahan bagi siswa Sekolah Dasar.

\section{Penggunaan Media Dalam}

\section{Pembelajaran}

Penggunaan media Papan Arsir Bongkar Pasang dapat memberikan kemudahan dalam memahami materi pecahan khususnya materi operasi hitung pecahan. media papan arsir ini memberikan pemahaman secara mendasar mengenai konsep operasi hitung pecahan dengan menggunakan teknik arsir. Berikut ini merupakan cara dalam penggunaan media papan arsir bongkar pasang dalam pembelajaran:

1. Guru mempersiapkan materi yang akan disesuaikan dengan penggunaan media papan arsir pecahan.

2. Guru menyiapkan media papan arsir pecahan yang lengkap dengan berbagai komponen yang ada dan memastikan tidak ada yang salah ataupun kurang.

3. Setelah semua telah terlaksana guru membuka pelajaran dan menjelaskan kepada siswa

4. Buka box media yang berisikan papan arsir dan spidol yang lengkap dengan komponen-komponen yang ada didalamnya. 
5. Guru menjelaskan kepada siswa mengenai komponen-komponen yang ada pada siswa.

6. Selanjutnya meletakkan papan utama pada dinding atau di atas meja. Peletakkan papan utama disesuaikan pada pelaksanaan pembelajaran dan memperhatikan posisi yang strategis untuk dapat dilihat oleh siswa dari berbagai sudut tempat duduk siswa.

7. Guru menjelaskan mengenai materi pecahan terlebih dahulu sesuai pemahaman siswa yang akan dihubungkan pada materi operasi hitung pecahan mulai dari penjumlahan, pengurangan, pembagian, dan juga perkalian.

8. Guru menyiapkan papan arsir transparan dan papan arsir tidak transparan untuk penjelasan materi.

9. Tuliskan dalam papan utama soal yang akan dijelaskan kepada siswa misalkan pada penjumlahan.

10. Setelah itu melakukan penjelasan kepada siswa mengenai arsiran pecahan sesuai dengan soal dari pecahan yang ada.

11. Ambillah spidol untuk mengarsir. Jika sudah diarsir, Dimulai pada papan arsir transparan kemudian papan arsir tidak transparan. Dalam pelaksanaan diperlukan pemahaman dan perasiran yang benar dan sesuai karena apabila salah arsir satu maka semua jawaban dapat tidak sesuai.

12. Letakkan papan arsir tidak transparan pada papan utama terlebih dahulu untuk proses peletakkan perhatikan pada kondisi vertikal pada arsiran yang ada pada papan arsir tidak transparan.

13. Yang kedua letakkan papan arsir transparan pada papan utama. letak papan arsir transparan berada di depan papan arsir tidak transparan hal ini bertujuan agar arsiran terlihat jelas. Perlu diperhatikan peletakkan papan arsir kedua atau papan arsir transparan dalam kondisi horizontal dari garis yang dibuat sesuai besar pecahan.

14. Setelah selesai terlihat maka akan muncul dan terlihat dari arsiranarsiran yang ada. Ada yang bertumpuk atau dobel dan ada yang tidak. Untuk proses pencarian jawaban sesuaikan pada rumus yang nantinya ada dalam buku petunjuk.

15. Guru menjelaskan kepada siswa untuk memperhatikan kedua papan arsiran dan menganalisis untuk menemukan jawaban dari soal yang ada.

16. Jika sudah mengetahui hasil maka tuliskan pada kolom hasil atau jawaban pada papan utama yang telah disediakan.

Dalam pelaksanaan pembelajaran menggunakan media pembelajaran papan arsir pecahan diperlukan pemahaman lebih bagi guru untuk menjelaskan pelaksanaan jawaban yang diperoleh dari rumus yang ada. Berikut ini merupakan beberapa rumus operasi hitung pecahan yang diterapkan dalam media pembelajaran papan arsir pecahan yang perlu diketahui :

\section{Pada penjumlahan}

Penjumlahan $=\underline{\text { Semua Arsiran }(\text { dobel dihitung } 2)}$ Semua Kotak

\section{Pada pengurangan}

Pengurangan $=\underline{\text { Jumlah Arsiran Kecuali Dobel }}$ Semua Kotak

\section{Pada perkalian}

Perkalian $=\frac{\text { Arsiran dobel }}{\text { Semua Kotak }}$ 


\section{Pada pembagian}

Pembagian $=\underline{\text { Semua Arsiran }(\text { tidak dan dobel })}$ Semua Kotak

Mencari jawaban yang ada pada soal disesuaikan dengan rumus tersebut, dalam menganalisis hasil atau jawaban haruslah sesuai pemahaman yang benar, agar tidak terjadi kesalahan sehingga menimbulkan kebingungan pada peserta didik.

\section{E. Prediksi Pembelajaran Menggunakan Media Papan Arsir Pecahan}

Papan arsir pecahan merupakan media yang memiliki banyak manfaat sebagai media pembelajaran penanaman konsep operasi hitung pecahan kepada siswa. Pertama, timbulnya rasa menyenangkan karena penyampaian materi pembelajaran yang lebih inovatif dan baru yang menerapkan media konsep operasi hitung pecahan sebelum memahami secara langsung. Kedua, meningkatkan pengetahuan tentang asal penjumlahan, pengurangan, perkalian, dan pembagian melalui proses berfikir lebih logis dan jelas dari awal atau konsep yang benar sesuai dengan kurikulum yang tersedia. Ketiga, menjadi solusi kreatif kejenuhan siswa dalam pembelajaran yang monoton. Adapun kesuksesan pengimplementasian dari media operasi hitung pecahan tidak lepas dari kerjasama dengan berbagai pihak antara lain:

\section{Kepala sekolah}

Kepala sekolah merupakan penanggung jawab segala hal yang ada dalam suatu sekolah salah satunya dalam hal pembelajaran. Kepala sekolah memiliki peran penting dalam kemajuan proses pembelajaran dengan memberikan wewenang dan pengawasan dalam pembelajaran. Untuk itu apabila media papan arsir pecahan digunakan sebagai salah satu alternatif pembelajaran diperlukan dukungan baik materil maupun moril dari pihak kepala sekolah.

2. Guru Sekolah Dasar

Guru Sekolah Dasar merupakan guru yang memiliki peran utama dalam proses pembelajaran di kelas. Guru akan memjadi acuan arah pelaksanaan pembelajaran. Guru sebagai pengguna media papan arsir pecahan memiliki peran dalam mengimplementasikan media papan arsir ini untuk digunakan di kelas dalam pembelajaran matematika khususnya materi operasi hitung pecahan.

3. Dinas Pendidikan

Kerjasama dengan dinas pendidikan merupakan salah satu alternatif yang tepat dalam pelaksanaan pembelajaran menggunakan media pembelajaran papan arsir pecahan dalam pembelajaran matematika. Dinas pendidikan memiliki peran mengevaluasi materi, sarana pendukung sosialisasi dalam pembelajaran mengggunakan media papan arsir pecahan.

\section{Penutup}

Media pembelajaran sebagai salah satu komponen pembelajaran memiliki peran penting dalam memberikan kemudahan dan juga pemahaman siswa dalam memahami materi operasi hitung pecahan. Media papan arsir pecahan merupakan salah satu alternatif pembelajaran matematika pada materi operasi hitung pecahan yang memiliki fungsi dan manfaat untuk menjelaskan tentang konsep operasi hitung pecahan mulai dari penjumlahan, pengurangan, perkalian dan pembagian. Dalam pelaksanaan pembelajaran matematika menggunakan media papan arsir pecahan 
diperlukan kerjasama dari pihak sekolah seperti kepala sekolah, guru, dan siswa. Hal ini akan berpengaruh pada pelaksanaan dan keberhasilan dalam pembelajaran matematika yang sesuai, benar, dan siswa tidak mengalami miskonsepsi.

\section{Daftar Pustaka}

\section{Buku}

Arsyad, Azhar. 2014 Media Pembelajaran. Jakarta: PT Raja Grafindo Persada.

Asyhar, Rayandra. 2012. Kreatif Mengembangkan Media Pembelajaran. Jakarta: PT.Referensi Persada.

Heruman. 2012. Model Pembelajaran Matematika di Sekolah Dasar. Bandung : Remaja Rosdakarya Offset.

Purnomo, Yoppy W. 2015. Pembelajaran Matematika Untuk PGSD. Jakarta: Erlangga

Sadiman, Arief dkk. (2009). Media Pendidikan: pengertian, pengembangan, dan pemanfaatannya. Jakarta :PT Raja Grafindo Persada.
Sani, Ridwan Abdullah. 2014. Inovasi Pembelajaran. Jakarta: Bumi Aksara.

Trianto. 2011. Model-Model Pembelajaran Inovatif Berorientasi Kontruktivitas. Jakarta: Prestasi Pustaka

Van de Walle, John A. 2008. Matematika Sekolah Dasar dan Menengah. Terjemahan Suyono. Jakarta: Erlangga.

\section{Jurnal}

Untary, Erni. 2013. "Diagnosis Kesulitan Belajar Pokok Bahasan Pecahan pada Siswa Kelas $V$ Sekolah Dasar". Jurnal Ilmiah STKIP PGRI Ngawi. Vol.13 (1): hal.1-8. 